\title{
Een feitenrijke wetenschap biedt nog geen antwoord op post-waarheid politiek ${ }^{*}$
}

\author{
Huub Dijstelbloem ${ }^{* *}$
}

De 'op de werkelijkheid gebaseerde gemeenschap' van de wetenschap geldt doorgaans als het betrouwbare ankerpunt dat tegenwicht moet bieden aan 'feitenvrije politiek' en 'post truth politics'. Wetenschappers en kritische journalisten die 'de waarheid' voorop willen stellen of - zoals dat tegenwoordig heet - 'het eerlijke verhaal' wensen te horen, vrezen dat door populistische politiek en irrationeel beleid het wetenschappelijk gezag de volgende autoriteit is die vogelvrij wordt verklaard. De kongsi van Donald Trump met Breitbart doet inderdaad het ergste voor de feiten en de waarheid vermoeden. In Nederland maakt de Koninklijke Nederlandse Academie van Wetenschappen (KNAW) zich dan ook grote zorgen:

'Wetenschappelijke bevindingen - feiten waarover grote consensus bestaat na langdurig en intensief onderzoek met herhaalde experimenten, hoor en wederhoor en open debat - [worden] steeds vaker weggezet als meningen.'

De president en vicepresident van de KNAW stellen dat:

'als deze houding van politici ten aanzien van wetenschappelijke bewijzen en feitelijkheid het nieuwe normaal gaat worden, de westerse cultuur een weg in slaat die sinds de Verlichting als een doodlopende straat werd beschouwd'. (Van Dijck \& Saarloos, 2017)

In zijn farewell address waarschuwde ook president Barack Obama dat mensen zich in toenemende mate zo veilig voelen in hun eigen bubbels dat ze slechts informatie aannemen die met hun eigen meningen strookt, of die nou klopt of niet, in plaats van die meningen te baseren op bewijzen. Obama ziet er een gevaar voor de democratie in:

'zonder gezamenlijke feitelijke basis en zonder bereidheid nieuwe informatie toe te laten en eventueel toe te geven dat onze opponenten wel eens een punt zouden kunnen hebben en dat wetenschap en de rede ertoe doen, praat iedereen langs elkaar heen'. (Obama, 2017)

De typering van de wetenschappelijke gemeenschap als een 'op de werkelijkheid gebaseerde gemeenschap' zullen veel wetenschapsbeoefenaars moeiteloos bea-

* Dit essay is gebaseerd op een lezing gehouden op het congres Goed werk voor academici. Over de beroepseer van wetenschappers ten huize van de KNAW op 1 november 2016.

** Prof. dr. Huub Dijstelbloem is werkzaam bij de faculteit der Geesteswetenschappen, capaciteitsgroep Philosophical Tradition in Context, Filosofie van Wetenschap en Politiek. 
men, gestoeld als hun werk is op empirisch onderzoek. Maar degenen die de discussie over feitenvrije politiek al wat langer volgen, proeven onraad. Zij weten dat de omschrijving stamt uit het artikel 'Faith, Certainty and the Presidency of George W. Bush' (Suskind, 2004). In dat artikel wordt een niet bij name genoemde politiek adviseur van George W. Bush aangehaald die later is geïdentificeerd als Karl Rove. Rove zei tegen Suskind dat mensen als hij leven in 'wat wij de op de werkelijkheid gebaseerde gemeenschap noemen', die hij definieerde als de mensen die 'geloven dat oplossingen ontstaan vanuit verstandige studie van een te onderscheiden werkelijkheid'. Maar, voegde hij daar aan toe 'dat is niet meer de manier waarop de wereld echt werkt'. Want:

'We zijn nu een imperium, en wanneer we handelen, creëren we onze eigen realiteit en terwijl jij die realiteit bestudeert, verstandig zo je wilt, handelen wij opnieuw en creëren we andere nieuwe werkelijkheden, die je ook kunt bestuderen, en dat is hoe het gaat. Wij zijn de actoren van de geschiedenis (...) en jullie, jullie allemaal, resteert niets anders dan te bestuderen wat we doen.' (Suskind, 2004)

Wat Rove hier beweerde, was niet simpelweg dat analyses door journalisten, politieke commentatoren en politieke wetenschappers achter de feiten aan lopen. Nee, hij stelde een compleet ander wereldbeeld voor, waar de analyse er helemaal niet meer toe doet. In plaats daarvan is het transformeren en het naar de hand zetten van de wereld de stuwende kracht.

Dat de wetenschappen een formidabele en ongeëvenaarde organisatie kennen voor het doen van systematisch onderzoek en de ontwikkeling van talloze inzichten op een zich immer uitbreidend aantal terreinen, behoeft nauwelijks betoog. Toch is het de vraag of de tegenstelling tussen 'feitenvrije politiek' en 'feitenrijke wetenschap' niet te simplistisch is en of de laatste de eerste überhaupt wel van repliek kan dienen. Zeker, politiek moet wetenschappelijk geïnformeerd zijn, en daaruit voorvloeiend beleid moet op een correcte analyse van werkelijke problemen gebaseerd zijn. Maar in politieke debatten en in de politieke ideeënstrijd hebben feiten ook een hele andere rol. Ze moeten zelfs een andere rol hebben, want als politiek alleen over feitelijkheid zou mogen gaan, is haar einde getekend. Politici worden immers niet gekozen om de wereld te beschrijven, maar om die te veranderen. Hun verhalen zijn niet primair representaties van de werkelijkheid, maar dienen ook om steun te verwerven, aanhang te smeden en de realiteit te kneden. Hoe verhoudt dat zich tot de 'feiten'?

Een interessante ingang tot deze kwestie biedt William Davies, auteur van The Happiness Industry: How the Government and Big Business Sold Us Well-Being (2015). Hij stelde in een opiniestuk (24 augustus 2016 in The New York Times) dat niet alleen de combinatie van populisme met sociale media, zoals vaak verondersteld, die feitenvrije politiek de wind in de zeilen geeft. Wat volgens hem een minstens zo sterke bijdrage levert is de opkomst van het gebruik en de analyse van big data. Door het voortdurende kiezersonderzoek en gebruikmaking van focusgroepen door de nauwgezette analyses van trending topics op Facebook, Google en Twitter kan continu worden nagegaan welk effect uitspraken hebben op wie. En 
kan daar met de opinie van de presidentiële kamer van de KNAW aan worden toegevoegd: big data beschouwen zowel feit als mening als inhoud. Big data zijn net zo goed in de politiek als in de wetenschap een hit.

Davies zelf maakt terecht een onderscheid tussen data en feiten. Dat maakt hij duidelijk aan de hand van een alledaags voorbeeld: het weerbericht. We begrijpen allemaal dat de voorspelling dat het komend weekend 9 graden wordt niet helemaal nauwkeurig is en zeker niet voor alle plekken in het land gedurende de hele dag op gaat. We reppen dan ook niet meteen van bedrog door het KNMI of van 'feitenvrije meteorologie' als het anders uitpakt. Volgens Davies moeten we data begrijpen als een soort narratief dat sentimenten teweegbrengt. Het brengt geen onomstotelijke robuuste feiten, maar een verhaal met gevoelswaarde Datzelfde geldt voor de politieke feiten. Die worden een narratief, waarbij het niet om het exacte waarheidsgehalte, maar om de temperatuur gaat. Dit, concludeert Davies, schept spannende mogelijkheden voor politici. Als getallen meer als indicatoren van sentiment worden gezien dan als stellingen over de werkelijkheid, hoe moeten we dan nog consensus bereiken over de aard van het sociale en economische milieu, laat staan tot overeenstemming komen over de oplossingen?

De vergelijking met het weer en het weerbericht is treffend, niet alleen vanwege de gevoelswaarde, warm of koud, zonnig of regenachtig; maar vanwege de activiteiten die mensen daaraan koppelen. Dat is namelijk precies wat politiek doet: op basis van feiten inschattingen maken van wat wel en niet mogelijk is, wat wenselijk is maar misschien onhaalbaar, en wat onwenselijk is en waar dus maatregelen tegen moeten worden getroffen. Een gezin dat het weerbericht ziet, plant daaromheen de activiteiten: 'Hé, het regent in het weekend, zullen we de dierentuin dan op woensdag doen?' 'Ja, dan verzetten we het zwemmen naar een binnenbad.' 'Oh ja, morgen toch maar de auto, de Jip en Janneke regencape voor Sem en Julia mee.' De feiten zetten de koers uit. Tegelijkertijd is het vanzelfsprekend dat er een marge in zit en dat het anders kan lopen - niets zo veranderlijk als het weer.

Zo bezien is het politieke debat meer te vergelijken met de buienradar dan met het Intergovernmental Panel on Climate Change. Dat is niet alleen omdat in de politiek feiten betekenis krijgen in de context van specifieke en uiteenlopende waarden en belangen. Dat is vooral zo omdat in de politiek aan feiten altijd een handelingsperspectief moet zijn gekoppeld: welke mogelijkheden openen de feiten? Frappant genoeg verschillen in dit opzicht wetenschap en politiek minder van elkaar dan veel commentatoren willen doen geloven. Naakte feiten bestaan ook in de wetenschap niet (Rheinberger, 1997). Wetenschappelijke feiten zijn altijd 'theoriezwanger'. Ze hebben pas betekenis in de context van specifieke aannames en achterliggende ideeën, en verschijnen pas met behulp van observaties, interviews of meetinstrumenten (zie bijvoorbeeld Brown, 2009). Het verschil tussen de werkelijkheid verklaren, beschrijven en beïnvloeden ligt in veel wetenschappen subtiel of is zelfs simpelweg afwezig (zie bijvoorbeeld Latour, 1987). Veel techno-science richt zich eerder op het ontwikkelen dan op het analyseren en op toepassingen in materialen, connectiviteit, slimme steden en zelfsturende auto's (zelf rijden deden ze al) (zie bijvoorbeeld Shapin, 2008). Wetenschap heeft een effect op de werkelijkheid. Economische modellen met aannames over evenwicht en gedrag 
van mensen worden toegepast en beïnvloeden zo de maatschappij. Sociaalwetenschappelijke concepten kunnen zelfs kloven in de samenleving veroorzaken - zie het onderscheid tussen autochtoon en allochtoon zoals dat lang in Nederlands beleid is gebruikt. Kortom, wetenschap maakt en voegt toe aan de wereld en vervormt deze.

De claim van 'naakte feiten' miskent bovendien dat niet alleen politiek maar ook wetenschap een handelingsgericht perspectief kent. Feiten kunnen in een proces van onderzoek, debat, besluitvorming en beleid nooit voldongen feiten zijn (zie voor uitvoerige besprekingen van dit punt en vele voorbeelden Dijstelbloem \& Hagendijk, 2011). In een commentaar in NRC Handelsblad schreef wetenschapsjournalist Hendrik Spiering (2016) over 'de strijd om waarheid en bruikbaarheid'. De specifieke aanleiding is borstkankeronderzoek en een test die het bedrijf Agendia, voortkomend uit het Nederlands Kanker Instituut, heeft ontwikkeld, genaamd 'MammaPrint'. Onder artsen heerst echter grote twijfel over de wetenschappelijkheid van de test en hoe het epidemiologisch onderzoek is opgezet, over de kosteneffectiviteit en vooral ook over hoe het gesprek over de resultaten van de test uitpakt in de spreekkamer. Kortom, de betekenis van feiten is niet alleen gebaseerd op de vraag of ze waar zijn of niet; daar bestaat al voldoende twijfel over. Minstens zo belangrijk is de vraag of ze het doel ondersteunen en of ze buiten het laboratorium een zinvolle bijdrage leveren. In wetenschap draait het zelden alleen om wat waarheid is, maar ook om wat waar bruikbaar voor is, of het betaalbaar is en welke richting van onderzoek gefinancierd moet worden.

De 'op de werkelijkheid gebaseerde gemeenschap' is zo bezien ook niet wars van bewerking van de werkelijkheid. Dat is geen diskwalificatie: wetenschappen die maatschappijen mede vormen zijn van onschatbare waarde. Evenmin is het kennistheoretische degeneratie: wetenschapsfilosofisch welbegrepen onderzoek dat zich niet bedient van een naïeve kijk op feiten wint aan methodologische kracht, versterkt en preciseert waarheidsclaims en verrijkt de onderzoeksbenadering.

De overeenkomsten tussen wetenschap en politiek maken echter ook dat er gevaren loeren. Ook in de wetenschap kan sprake zijn van bubbels. Katharine Viner, hoofdredacteur van The Guardian, vroeg zich vorig jaar in haar essay How Technology Disrupted the Truth (2016) af of de waarheid er nog wel toe doet in media en politiek. Volgens haar is wat telt als een feit in toenemende mate afhankelijk van de vraag of iemand het gevoel heeft dat het waar is. En door de communicatietechnologie circuleren dat soort gevoelswaarheden vervolgens in het publieke domein. Het is uiterst moeilijk, beaamt Viner, voor mediabedrijven daar niet in mee te gaan. De consument zit aan het stuur en het clickmodel is in belangrijke mate het verdienmodel geworden.

Ook de wetenschap is niet van bubbels gevrijwaard. In een interview waarschuwde hoogleraar bestuurskunde Mark Bovens:

'Als je alleen op de universiteit hebt gewerkt of gestudeerd, besef je waarschijnlijk niet dat je in een bubbel leeft. Dan denk je dat iedereen denkt zoals jij en je vrienden, kennissen en collega's. Dat is dus zeker niet het geval.' (Bovens, 2016) 
Het gevaar dreigt bovendien dat op de universiteiten verschillende scholen, benaderingen en paradigma's niet meer met elkaar in gesprek gaan. Ook de wetenschappen zelf zijn niet gevrijwaard van bubbels. Bubbels bestaan in de vorm van verschillende onderzoeksgroepen en benaderingen of paradigma's, die in plaats van met elkaar in debat te zijn hun eigen ecologie van universitaire afdelingen, tijdschriften en congressen hebben, waardoor het simpelweg helemaal niet nodig is een gesprek met andersdenkenden aan te gaan. Bubbels ontstaan ook door hoop en opgeklopte verwachtingen en regelrechte speculatie: door grote investeringen of de inbreng van risicokapitaal in bijvoorbeeld de neurowetenschappen en medisch onderzoek moeten de verwachtingen wel worden waargemaakt of, zolang dat nog niet helemaal het geval is, in ieder geval levend worden gehouden (Rose, 2007). Robbert Dijkgraaf (2016) stelde daarom:

'Als de wetenschap dus iets zou moeten doen is het intellectuele diversiteit bevorderen en ideologische zeepbellen doorprikken, niet alleen in de samenleving maar ook in eigen huis: op de universiteit.'

Een andere mogelijkheid oppert Kathleen Higgins (2013), hoogleraar aan de University of Texas, Austin. Met een beroep op het perspectivisme van Friedrich Nietzsche pleit zij voor wat ze noemt 'post truth pluralism': 'post-waarheid pluralisme'. Ze begint met de stelling dat mensen met een progressieve overtuiging en welke wetenschapsbeoefenaar heeft die niet - gelijk hebben dat we in een postwaarheid tijdperk leven. Maar anders dan dit te verwerpen en terug te verlangen naar een meer waarheidlievende tijd moeten we volgens haar door het post-waarheid tijdperk leren te navigeren om liberale waarden te promoten:

'In plaats van politieke meningsverschillen terug te brengen tot zwart-wit categorieën van feit en fictie, moeten we Nietzsche's les serieus nemen dat waarheid altijd een functie is van de wil om de wereld te beschrijven, en dat de pluraliteit aan gezichtspunten een noodzakelijke eigenschap in plaats van een obstakel is om democratie verder te ontwikkelen.'

Als daar een kern van 'waarheid' in zit, is het volgen van de temperatuur van de waarheid nog niet zo'n slecht idee.

Maar hoe doe je dat, de temperatuur van de waarheid meten? Of de 'factchecker' uitkomst biedt, valt te betwijfelen. In ieder geval niet met de pretentie dat die de naakte waarheid presenteert of met een 'full stop' de betekenistransformatie van feiten kan afdwingen. Het is ronduit potsierlijk als het wetenschappelijke tegenwicht bestaat uit een stukje in de krant van 200 woorden waarin opgedoken stellingen op een schaal van 'waar' tot 'leugen' worden beoordeeld.

Bovendien: kunnen feiten wel overtuigen? Zoals David Runciman, auteur van The Confidence Trap: A History of Democracy in Crisis from World War I to the Present (2013), in The Guardian liet zien is de scheidslijn tussen hoger en lager opgeleiden een van de meest diepe in het politieke landschap. Meer feiten bieden en meer kennis overdragen zou dan een strategie zijn om die kloof te overbruggen. Echter, Runciman (2016) betoogt dat opleidingsniveau geen onafhankelijke factor is, 
maar zelf is ingebed in een breder geheel van waarden, levensopvattingen en wereldbeelden. Zo bezien krijgt de uitspraak van Michael Gove tijdens de Brexitcampagne dat de mensen het wel gehad hebben met experts een andere betekenis. Wantrouwen jegens experts is niet zozeer geboden omdat ze onwaarheden vertellen. Wantrouwen is nodig omdat de feiten die ze presenteren vanuit een bepaalde maatschappelijke positie worden gebracht. Feiten betekenen hier: macht en vooral definitiemacht. Meer feiten of zelfs betere feiten is dan niet het antwoord.

Het debat over de positie die de wetenschappen moeten innemen om tegenwicht te bieden aan feitenvrije politiek zal niet snel overwaaien. De huidige antwoorden voldoen echter nog niet. Debet daaraan is een weinig ontwikkelde wetenschapsfilosofische, wetenschapssociologische en wetenschapspolitieke reflectie op het eigen metier en de centrale begrippen ervan. Een te simplistisch onderscheid tussen 'feitenvrije politiek' en 'feitenrijke wetenschap' miskent de rol van feiten en van waarden in zowel wetenschap als politiek en heeft te weinig oog voor de onderlinge interacties. Voor een positiebepaling die op een meer realistisch beeld van wetenschap is gebaseerd zijn drie lessen te trekken.

De eerste les is dat een reductie van wetenschap tot een 'beroep op de feiten' wetenschapsfilosofisch gesproken een nogal naïeve en uiteindelijk zelfs weinig productieve positie is. Naïef omdat (a) zo de vraag wat als 'feit' mag gelden buiten discussie wordt geplaatst, (b) de kwestie wat te doen als verschillende geldige benaderingen met hele andere feiten komen niet wordt beantwoord, en vooral (c) omdat de veel belangrijkere zaak dat verschillende wetenschapsgebieden andere verhoudingen tussen feiten, uitspraken, theorieën en waarnemingen laten zien, zo aan de aandacht wordt onttrokken. In plaats daarvan zullen wetenschapsbeoefenaars veel explicieter moeten zijn over waarom die feiten ertoe doen en welke veranderingen ze teweeg kunnen brengen.

De tweede les is dat wetenschap niet het alleenrecht en zeker niet het laatste woord over de betekenis van feiten heeft. Wetenschap mag over de beste papieren beschikken om met correcte feiten te komen. Welke waarde daaraan wordt toegekend, is echter een zaak van politiek en publiek debat. Academisch farmaceutisch onderzoek kan een nieuw geneesmiddel ontwikkelen, maar of dat wel beter werkt dan bijvoorbeeld bestaand voorlichtings- en preventiebeleid, of de kosten tegen de baten opwegen en of dat geen medicalisering van een bepaald verschijnsel oplevert, zijn maatschappelijke vragen waarop het publiek en politiek debat antwoord moeten geven.

De derde les is dat de betekenis van feiten afhangt van zowel de verschillende waardesystemen en wereldbeelden die mensen hanteren als van de diverse handelingsperspectieven die ze toelaten. Het zit dus wat ingewikkelder in elkaar dan dat de wetenschap de werkelijkheid verklaart of beschrijft en de politiek de wereld in beweging moet brengen. Ook wetenschap is een vormende kracht. Die streeft weliswaar naar waarheid, maar transformeert ondertussen de wereld ook door er allerlei begrippen, uitvindingen en toepassingen aan toe te voegen. Dat verplicht tot voortdurende bezinning op het wetenschappelijk werk. Het is niet 'slechts' kennis dat de universiteiten voortbrengen. Ze veranderen de maatschappij ook, 
op een eigen manier. Dat onderkennen strekt tot eer en verplicht tot verantwoordelijkheid.

\section{Literatuur}

Brown, M. (2009). Science in Democracy. Expertise, Institutions, and Representation. Cambridge, Mass.: The MIT Press.

Bovens, M. (2016). Interview in DUB 8 november 2016. www.dub.uu.nl/artikel/ achtergrond/er-gevaar-dat-universiteiten-zich-loszingen-rest-samenleving.html, geraadpleegd op 10 januari 2017.

Davies, W. (2015). The Happiness Industry: How the Government and Big Business Sold Us Well-Being. Londen: Verso.

Davies, W. (2016, 24 augustus). The Age of Post-Truth Politics. The New York Times.

Dijck, J. van, \& Saarloos, W (2017, 2 januari). Wetenschap is niet 'maar een mening'. NRC Handelsblad.

Dijkgraaf, R. (2016, 30 september). Ieders eigen ideologische zuurstoffles. NRC Handelsblad.

Dijstelbloem, H., \& Hagendijk, R. (red.) (2011). Onzekerheid Troef. Het betwiste gezag van de wetenschap. Amsterdam: Van Gennep.

Higgins, K. (2013). Post-Truth Pluralism. The Unlikely Political Wisdom of Nietzsche. http:// thebreakthrough.org/index.php/journal/past-issues/issue-3/post-truth-pluralism, geraadpleegd op10 januari 2017.

Kraaijeveld, K. (2016, 8 oktober). We zijn de waarheid uit het oog verloren. De Volkskrant.

Latour, B. (1987). Science in Action. Cambridge, Mass.: Harvard University Press.

Obama, B. (2017). Farewell adress president Obama, Chicago. Zie voor een transcript bijvoorbeeld www.whitehouse.gov/farewell, geraadpleegd op 12 januari.

Rheinberger, H.J. (1997). Toward a History of Epistemic Things. Synthesizing Proteins in the Test Tube. Palo Alto: Stanford University Press.

Rose, N. (2007). The Politics of Life Itself. Biomedicine, Power, and Subjectivity in the TwentyFirst Century. Princeton: Princeton University Press.

Runciman, D. (2013). The Confidence Trap: A History of Democracy in Crisis from World War I to the Present. Princeton: Princeton University Press.

Runciman, D. (2016, 5 oktober). How the education gap is tearing politics apart. The Guardian.

Shapin, S. (2008). The Scientific Life, A moral history of a late modern vocation. Chicago/Londen: The University of Chicago Press.

Spiering, H. (2016, 15 oktober). De strijd om waarheid en bruikbaarheid. NRC Handelsblad. Suskind, R. (2004, 17 oktober). Faith, Certainty and the Presidency of George W. Bush. The New York Times Magazine.

Viner, K. (2016, 12 juli). How Technology Disrupted the Truth. The Guardian. 